\title{
Potential of Moringa oleifera (Lam.) fresh root-bark extract as an organic piscicide in aquaculture pond management
}

\section{B.T. Adesina ${ }^{* 1}$ \& B.O. Omitoyin ${ }^{2}$}

1 Department of Animal Science \& Fisheries, Osun State University, PMB 4494 Osogbo, College of Agriculture, Ejigbo, Nigeria

2 Department of Wildlife \& Fisheries Management, Faculty of Agriculture \& Forestry, University of Ibadan, Nigeria

\begin{abstract}
This study examined the effectiveness of Moringa oleifera fresh root-bark extract as an organic piscicide to control predatory fish in ponds. Acute-lethal toxicity $\left(\mathrm{LC}_{50}\right)$ of Moringa oleifera extract for 96-h exposure for Oreochromis niloticus fingerlings was determined at $26.45 \mathrm{mg} \mathrm{l}^{-1}$. The extract was more toxic at higher concentrations of $100 \mathrm{mg} \mathrm{l}^{-1}$, with fingerlings showing abnormal swimming, restlessness and uncoordinated behaviour before death. Moringa oleifera extract could be used as an organic piscicide in aquaculture pond management. Baseline information on its toxicity to fish could serve as a tool in fisheries management to wipe out predatory fish in ponds prior to stocking.
\end{abstract}

Keywords: Toxicity, Oreochromis niloticus, Fisheries management, $\mathrm{LC}_{50}$

\section{Introduction}

Elimination of unwanted fish is a common practice among fish farmers prior to stocking with desirable fish fingerlings. However, the synthetic piscicides used to eliminate unwanted fish are persistent and could get into the food chain. Thus the use of environmentally safe organic piscicides as an alternative is being embraced in aquaculture because they are biodegradable over short time periods, and there is the possibility that fish killed by them are edible with no health hazards (Chiayvaresajja et al. 1997; Agbon et al. 2004; Akinbulumo et al. 2004; Akinwade et al. 2007). Some organic piscicides have been identified and used by different researchers around the world as fish pond management tools to eradicate predators in fish ponds (Adewole 2002; Tiwari et al. 2003; Adeogun 2004; Agbon et al. 2004; Tiwari \& Singh 2004; Tiwari 2005). These organic piscicides include extracts from plants such as Parkia biglobosa, Raphia hookeri, Derris elliptica, Euphorbia tirucalli and Nerium indicum.

Currently, there is scanty information in the literature as regards the use of fresh rootbark extracts of Moringa oleifera as an organic piscicide in aquaculture pond management in the developing world. Moringa oleifera is a tree belonging to the family Moringaceae, usually growing outside the forest areas of south-western Nigeria (Adesina et al. 2008). The tree is under-utilized and contains several toxic compounds, such as phenol, tannins, saponins, glucosinolates, oxalic acid, lectins, moringine and moringinine (alkaloids), pterygospermin, spirochin and benzyisothiocyanate (Berger et al. 1984; Grabow et al. 1985; Makkar \& Becker 1997; Fuglie 2001; Fahey 2005; Wise 2006). Moringa oleifera is suggested as an alternative to synthetic piscicides because it is commonly available, is less expensive for fish farmers and has a lower toxicity against non-target species. Its piscicidal potential is embedded in the rootbark which contains the alkaloids that act on the nervous system of fish and other terrestrial animals (Fuglie 2001; Adesina 2008).

Therefore the objective of this research was to determine the acute lethal toxicity $\left(\mathrm{LC}_{50}\right)$ of Moringa oleifera fresh root-bark extract to Oreochromis niloticus fingerlings exposed for $96 \mathrm{~h}$.

\footnotetext{
* Author for correspondence: tel +23408038357765 email : isajin1999@yahoo.com
} 


\section{Materials \& Methods}

180 Oreochromis niloticus L. fingerlings were obtained from the fish farm of the Wildlife \& Fisheries Management Department, University of Ibadan, Nigeria. The fingerlings selected for the experiment had a mean total length of $5.41 \pm 0.25 \mathrm{~cm}$ and weight $5.4 \pm 0.28 \mathrm{~g}$, with no record of prior exposure to the toxicant. The fishes were held in translucent plastic 55-litre aquaria covered with transparent mosquito net to prevent fish from jumping out of the aquaria during the experiment: aeration of the dechlorinated water was constantly maintained. The fish were acclimated for 14 days, and fed twice daily with commercial floating feed containing $30 \%$ protein; they were fed $3 \%$ of their body weight as a maintenance ration (Bhagwant \& Bhikajee 2001; Omitoyin et al. 2006). Unused feed and faeces were siphoned out daily to prevent water contamination (Oyelese \& Faturoti 1995).

Fresh roots of Moringa oleifera were collected from the nursery unit of the Department of Forestry Resources Management, University of Ibadan. The bark was removed, cut into pieces with a knife, and later ground with a pestle and mortar to obtain macerated samples. Aqueous extracts were obtained using a cold-water extraction technique in order to simulate local procedures (Ofogba et al. 1998). $50 \mathrm{~g}$ of macerated freshly prepared samples of root-bark were weighed into a conical flask, $100 \mathrm{ml}$ distilled water added and shaken before filtering using a dry whatman filter paper, and then the filtrate poured into a 100-ml graduated measuring cylinder. The cold-water extract was stored at $4{ }^{0} \mathrm{C}$ inside a refrigerator for immediate use.

A preliminary toxicity test was conducted (Odiete 1999; Reish \& Oshida 1986; Pandey et al. 2008) using a spacing factor of 10 to determine the lethal concentrations $\left(\mathrm{LC}_{50}\right)$ of over $24 \mathrm{~h}$. The following concentrations of fresh extract were prepared by dissolving $50 \mathrm{~g}$ in $100 \mathrm{ml}$ distilled water, and serially diluting to produce $5000 \mathrm{mg} \mathrm{l}^{-1}$ per 51 water (Odiete 1999): 0, 0.1, $1,10,100,1000 \mathrm{mg} \mathrm{l}^{-1}$. The fish were starved for $24 \mathrm{~h}$ before the experiment. Five fish were tested on each concentration, and the mortality and clinical behaviour monitored and recorded after the toxicant was introduced into the aquaria. The definitive toxicity test referred to as acute toxicity was carried out based on the results of the prelimary test, but a spacing factor of 1.8 and a duration of $96 \mathrm{~h}$ were used (as earlier described by Odiete 1999).

Ten fingerlings of Oreochromis niloticus starved for $48 \mathrm{~h}$ were released into each aquarium of 55 litres capacity, and one of the following concentrations of extract introduced: 0 , $10,17,31,56$ and $100 \mathrm{mg} \mathrm{l}^{-1}$. Fish mortality was monitored and recorded hourly for the first 4 $\mathrm{h}$, every $4 \mathrm{~h}$ for the next $24 \mathrm{~h}$, and subsequently every $24 \mathrm{~h}$ until the time limit of $96 \mathrm{~h}$ (Ayotunde \& Ofem 2008). The inability of fish to respond to external stimuli was used as an index of death (Ayotunde \& Ofem 2008). Fish behaviour such as erratic swimming, air gulping, loss of reflex, discolouration and moulting was monitored during the experiment. The experimental design was a complete randomized design with six treatments and three replicates per treatment.

Water quality monitoring was carried out prior to, during and after the experiment. The physico-chemical parameters of the water (dissolved oxygen, temperature and $\mathrm{pH}$ ) were measured using the APHA (1998) method of water quality assessment. Mortality data were analysed using probit software of USEPA (2000). The median lethal concentration $\left(\mathrm{LC}_{50}\right)$ at the selected period of exposure and associated 95\% confidence interval for each replicate toxicity test was subjected to logit and probit analysis (Finney, 1971). Water quality parameters were subjected to one way analysis of variance.

\section{Results}

Control fish showed no abnormal behaviour during the experimental period of $96 \mathrm{~h}$. Fish treated with the highest concentration of $100 \mathrm{mg} \mathrm{l}^{-1}$ of Moringa extract showed various toxic 
reactions, such as erratic swimming, restlessness, air gulping, increased opercular beat. These abnormal behaviours progressively (through time) manifested themselves in the other lower concentrations of $10,17,31$, and $56 \mathrm{mg} \mathrm{l}^{-1}$. Increases in concentration and exposure time resulted in loss of scales and haemorrhages in exposed fish. Dead fish were covered with excessive mucus, and fish died with stiff fin rays. The highest mortality was recorded at 100 $\mathrm{mg} \mathrm{l}^{-1}$ over $96 \mathrm{~h}$ (Table 1 ).

\begin{tabular}{|r|r|}
\hline $\begin{array}{l}\text { Concentration } \\
\text { of extract } \\
\left(\mathrm{mg} \mathrm{l}^{-1}\right)\end{array}$ & $\begin{array}{l}\text { Mortality out } \\
\text { of } 30\end{array}$ \\
\hline 0 & 0 \\
\hline 10 & 8 \\
\hline 17 & 9 \\
\hline 31 & 11 \\
\hline 56 & 21 \\
\hline 100 & 30 \\
\hline
\end{tabular}

Table 1: Acute toxicity of Moringa oleifera fresh root-bark cold-water extract applied to Oreochromis niloticus fingerlings for $96 \mathrm{~h}$. Each replicate involved 10 fish. The slope of the probit analysis of mortality against concentration was $2.12 \pm 0.60$ (95\% confidence limits 0.958 to 3.295$)$. $\mathrm{LC}_{50}$ was estimated at $26.5 \mathrm{mg} \mathrm{l}^{-1}$ (95\% confidence limits 15.3 to 42.0 ).

\section{Discussion}

The water quality parameters obtained in the present study are within the range of water quality recommended for culturing tilapia species (Olaifa et al. 2008; Ayotunde \& Ofem 2008; Adesina 2008). Fingerlings of Oreochromis niloticus exhibited a range of abnormal behaviours at higher concentrations of the Moringa extract; normally, fish exposed to toxicants exhibit different behavioural changes (Santhakumar \& Balaji 2000; Fafioye 2001; Ayuba \& Ofojekwe 2002, Chung-MinLiao et al. 2003; Adeogun 2004; Adesina 2008; Ayotunde \& Ofem 2008; Olaifa et al. 2008; Pandey et al. 2008) that adapt them to the toxin. Here, fish exposed to higher concentrations exhibited toxic reactions that later resulted in death (Fafioye 2001; Fafioye et al. 2004; Omitoyin 2006). Mortality was dose-dependent and increased with time.

The $\mathrm{LC}_{50}$ value for Oreochromis niloticus fingerlings $\left(26.5 \mathrm{mg} \mathrm{l}^{-1}\right)$ is quite high; estimates vary in different fish species and in the same species under different conditions (Omitoyin et al. 1999; Omitoyin et al. 2006; Pandey et al. 2008). Verma et al. (1982) recorded values of 5.14, 4.8, 4.67 and $4.57 \mathrm{mg} \mathrm{l}^{-1}$ for $24,48,72$, and $96 \mathrm{~h}$ respectively in Heteropneustes fossilis exposed to dimethoate; at different seasons the $96-\mathrm{h}$ values were 14.39 and $2.98 \mathrm{mg} \mathrm{l}^{-1}$ for the dry and wet season respectively (Pandey et al, 2008). The 96-h $\mathrm{LC}_{50}$ of pawpaw seed powder was $18 \mathrm{mg} \mathrm{l}^{-1}$ (Ayotunde \& Ofem 2005). Some species are very resistant to some taxons: for example, 5878, 4865 and $610 \mathrm{mg} \mathrm{l}^{-1}$ were recorded for Sarotheordon galilaeus exposed to ethanolic extracts of cocoa bean shell (Olaifa et al. 2008). A 96-h LC $_{50}$ value for dimethoate on Clarias batrachus was $65 \mathrm{mgl}^{-1}$ (Begum \& Vijayraghvan, 1995).

Differences observed in the values of $\mathrm{LC}_{50}$ from the current research as compared to other values obtained elsewhere show that fish become more sensitive to any toxicant with greater exposure times; increased mortality is also know to result from increased temperatures (Patra et al 2007). Variation in $\mathrm{LC}_{50}$ thus depends on a number of biological and physicochemical factors, reported by many earlier workers (Pandey et al. 2008). 
In conclusion, fish exposed to fresh root-bark extract of Moringa oleifera at different concentrations exhibited toxic responses which eventually lead to death. This extract could be used as an organic piscicide in aquaculture pond management, and baseline information on its toxicity to fish could serve as a fisheries management tool to wipe out predatory fishes in ponds prior to stocking.

\section{Acknowledgements}

We would like to thank Miss Oguntuga Adedayo for assisting with the preparation of the plant extract in the laboratory. We thank Dr LA Adebisi, the Acting Head of the Department of Forestry Resources Management, University of Ibadan for identifying the plant used in this research.

\section{References}

Adeogun OA (2004) Effects of methanolic extract of Raphia hookeri (Mann \& Wendl 1804) on life stages of Clarias gariepinus (Burchell, 1822). PhD Thesis University of Ibadan, Nigeria, 306pp.

Adesina BT (2008) Toxicity of Moringa oleifera (Lam.) extract to Oreochromis niloticus fingerlings and juveniles. PhD Thesis, University of Ibadan, Nigeria. 272pp.

Adesina BT, Omitoyin BO, Agbeja BO, Adebisi LA \& Adeyemo AA (2008) Effectiveness of Moringa oleifera Lam. seeds as a natural coagulant in public water treatment. Obeche Journal 26(1): 68-77

Adewole AM (2002) Evaluation of chemical components of some fish toxic plants in Ibadan. MPhil dissertation, University of Ibadan, Nigeria. 241pp.

Agbon A, Ofojekwe C \& Ezenwaka I (2004) Acute toxicity of water extract of Tephrosia vogelii Hook to species relevant in aquaculture ponds: rotifers, Cyclops, mosquito larvae and fish. Journal of Applied Ichthyology 20: $521-525$

Akinbulumo MO, Fagbenro OA \& Fasakin EA (2004) Acute toxicity of ethanolic extract of Derris elliptica root to Oreochromis niloticus fingerlings. In: Proceedings of an International Symposium on Tilapia aquaculture, Manilla, Philippines, 12-16 September. Accessed on line http://ag.arizona.edu/azaque/ista/istab/istabweb/ web/health.httm on 10/24/2006. pp 223.

Akinwande AAA, Sogbesan AO, Moody FO \& Ugwumba AAA (2007) Piscicidal potential of mesocarp of neem plant (Azadirachta indica A.Juss.) fruit on hybrid, "Heteroclarias". Journal of Environmental Biology 28(3): 533-6

APHA (American Public Health Association) (1998) Standard methods for the examination of water and waste water. $20^{\text {th }}$ edition, New York, USA. $1976 \mathrm{pp}$.

Ayotunde EO \& Ofem BO (2005) Acute and chronic toxicity of pawpaw (Carica papaya) seed powder to Nile tilapia, Oreochromis niloticus (Linne 1757) fingerlings. Journal of Science, Agriculture, Food Technology \& Environment 1(1).

Ayotunde EO \& Ofem BO (2008) Acute and chronic toxicity of pawpaw to adult Nile tilapia (Oreochromis niloticus (Linne 1757). African Journal of Biotechnology 7(13): 2265-74

Ayuba VO \& Ofojekwe PC (2002) Acute toxicity of the Simson's Weed (Datura innoxia) to the African Catfish (Clarias gariepinus) fingerlings. Journal of Aquatic Sciences 17(2): 16

Begum G \& Vijayaraghavan S (1995) In vivo toxicity of dimethoate on protein and transaminases in the liver tissue of freshwater fish Clarias batrachrus (Linn.). Bulletin of Environmental Contamination \& Toxicology 54: $370-375$

Berger MR, Habs M, Jahn SAA \& Schmahl D (1984) Toxicological assessment of seeds from Moringa oleifera and Moringa stenopetala, two highly efficient primary coagulants for domestic water treatment of tropical raw waters. East African Medical Journal 61: 712-6

Bhagwant S \& Bhikajeee M (2000) Introduction of hypochromic macrocytic anaemic in Oreochromis hybrids (Cichlidae) exposed to $100 \mathrm{mg} / \mathrm{l}$ (sublethal dose) of aluminium. Journal of Science \& Technology 5: 10-20

Chiyvareesajja S, Rittibhonbhun N, Hongpranyart M \& Wiriyacchitra P (1997) Toxicity of the Thai piscicidal plant Maesa ramentacea to freshwater fish in ponds. Aquaculture 158(3/4): 229-34

Chung-Min L, Bo-ching C, Sher S, Ming-Chaalin, Chen-Wuing L \& Borcheng H (2003) Acute toxicity and bioaccumulation of arsenic in tilapia (Oreochromis mossambicus) from a black foot disease area of Taiwan. Environmental Toxicology 18 (4): 252-259

Fafioye OO (2001) Lethal and sublethal effects of Parkia biglobosa and Raphia vinifera on some freshwater fauna. PhD Thesis, University of Ibadan, Nigeria. $216 \mathrm{pp}$.

Fafioye OO, Adebisi A \& Fagade SO (2004) Toxicity of Parkia biglobosa and Raphia vinifera extract on Clarias gariepinus juveniles. African Journal of Biotechnology 3(2): 627-630

Fahey JW (2005) Moringa oleifera: a review of the medical evidence for its nutritional, therapeutic and prophylactic properties. Part 1. Trees for life Journal 1: 5

Finney DJ (1971) Statistical methods in biological assays. $2^{\text {nd }}$ edit. Hafner Co. New York. 68p 
Fuglie LJ (2001) The miracle tree: the multiple attributes of Moringa, CTA, ACP and Church World Service Publication Dakar, Senegal.

Grabow WOK, Slabert JL, Morgan WSG \& Jahn SAA (1985) Toxicity and mutagenicity evaluation of water coagulated with Moringa oleifera seed preparations using fish, protozoan, bacterial, coliphage, enzyme and Ames Salmonella assays. Water South Africa 11(1): 9-14

Makkar HPS \& Becker K (1997) Nutrients and antiquality factors in different morphological parts of the Moringa oleifera tree. Journal of Agriculture, Cambridge 128: 311-322

Odiete WO (1999) Environmental physiology of animals and pollution. Diversified Resources, Ltd., Lagos, Nigeria. 261 pp.

Ofogba CJ, Agbomo FU, Abdul-Kareem FB, Abaelu AM \& Alatishe K (1998) Effect of Bridelia ferruginea stem bark on blood chemistry and histology of some organs in rats. Nigerian Journal of Natural Products \& Medicine 2: 26-28

Olaifa FE, Hamzat RA \& Oyetoyan OO (2008) Acute toxicity of ethanol extracts of Cocoa bean shell on Sarotherodon galilaeus juveniles. Journal of Fisheries International 3(3): 56-60

Omitoyin BO, Ajani EK, Adesina BT \& Okuagu CNF (2006) Toxicity of Lindane (gamma-hexachlorocyclohexane) to Clarias gariepinus (Burchell, 1822). World Journal of Zoology 1(1): 57-63

Omitoyin BO, Ogunsanmi AO \& Adesina BT (1999) Studies on acute toxicity of piscicidal plant (Tetrapleura tetraptera) extract on tilapia (Sarotherodon galilaeus) fingerlings. Tropical Journal of Animal Science 2(2): 191-197

Oyelese OA \& Faturoti EO (1995) Growth and mortality estimates in Clarias gariepinus fed graded levels of processed cassava peels. Journal of Tropical Forest Resources 11: 71-81

Pandey RK, Singh RN \& Das VK (2008) Effects of temperature on mortality and behavioural responses in freshwater catfish, Heteropneustes fossilis (Bloch) exposed to dimethoate. Global Journal of Environmental Research 2(3): 126-132

Patra RW, Chapman JC, Lim RP \& Gehreke PC (2007) The effects of three organic chemicals on the upper thermal tolerance of four freshwater fishes. Environmental Toxicology \& Chemistry 26(7): 1454-9

Reish DL \& Oshida PS (1987) Short-term bioassay. In: Manual of methods in aquatic environmental research Part 6. FAO, FAO Fisheries Technical Paper No 247: 1-62

Santhakumar M \& Balaji M (2000) Acute toxicity of an organo-phosphorus insecticide monochrotophos and its effects on behaviour of an air-breathing fish, Anabas testudineus (Bloch). Journal of Environmental Biology 21(2): 21-123

Tiwari S \& Singh A (2005) Possibility of using latex extracts of Nerium indicum plant for control of predatory fish, Channa punctatus. Asia Fisheries Science 18: 161-173

Tiwari S \& Singh A (2004) Piscicidal activity of alcoholic extracts of Nerium indicum leaf and their biochemical stress response on fish metabolism. African Journal of Traditional, Complementary \& Alternative Medicines 1(1): 15-29.

Tiwari S, Singh P \& Singh A (2003) Toxicity of Euphorbia tirucalli plant against freshwater target and non-target organisms. Pakistan Journal of Biological Science 6(16): 1423-9

USEPA (2000) Methods for measuring the acute toxicity of effluents to freshwater and marine organisms. $4^{\text {th }}$ Ed. Environmental Monitoring and Support Laboratory, US. Environmental Protection Agency, Cincinati, Ohio, EPA 600/4-85/013.

Verma SR Bansal SK, Gupta AK, Pal N, Tyagi AK, Bhatnagar MC, Kumar V \& Dalela RC (1982) Bioassay trials with twenty-three pesticides to a freshwater teleost Saccobranchus fossilis. Water Research 16: 525-9

Wise R (2006) Moringa oleifera: Medicinal and socio-Economic uses. International course on Economic Botany, September, 2006. National Herbarium, Leiden, the Netherlands. 


\section{الملخص العربي}

\section{الاستخدامات الممكنة لمستخلصات الجذور الطبيعية لأشجار البان (Lam) كمبيد عضوي للأسماكو يسهم في التحكم في أحواض تربية المئه الأحياء المائية}

$$
\text { ب.ت. أدسينا } 1 \text { \& ب.أ. أوميتوين2 }
$$

1 قسم علوم الحيو ان و المصايد، جامعة و لاية أوسون، ص.ب. 2 قسم إدارة الحياة البرية و المصايد، كلية الزراعة والية الغابنات، جامعة إبادان، نيجيريا.

بحثت هذه الدراسةّ فعالية الخلاصة الطبيعية لجذور أشجار المورينجا في العمل كمبيد عضوي للتحكم في الأسماك المفترسة

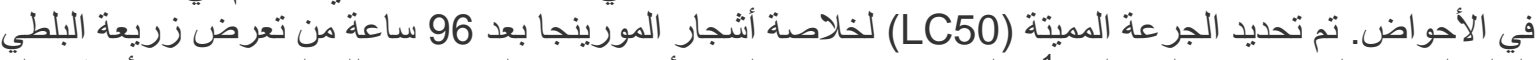

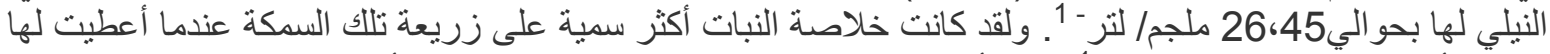

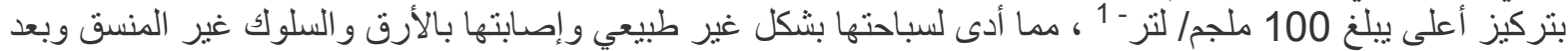

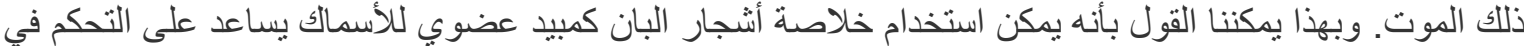

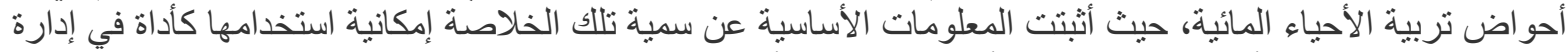
المصايد للقضاء على الأسماك المفترسة في أحو اض تربية الأسماك قبل تخزينها. 